\title{
Understanding the Bases and Approaches of Mortgage Valuation in Ethiopia
}

Habtamu Bishaw Asres 1, Hans Lind 2, and Belachew Yirsaw Alemu 3

1, 3 Institute of Land Administration, Bahir Dar University, Ethiopia.

2 School of Architecture \& Built Environment, KTH Royal Institute of Technology, Sweden.

To cite this article: Asres, H.B., Lind, H. \& Alemu, B.Y. (2020). Understanding the Bases and Approaches of Mortgage Valuation in Ethiopia. Journal of African Real Estate Research, 5(1), pp.55-76. DOI: 10.15641/jarer.v5i1.856.

\begin{abstract}
In Ethiopia there is no mortgage valuation framework or a regulatory valuation institution. Due to this, financial institutions may value mortgage securities without any clear and consistent basis; resulting in confusion among experts and parties dependent on valuations for their business. Further, there is no previous empirical evidence on how banks or financial institutions value mortgage securities. This study is therefore intended to examine the practice of mortgage valuation adopted by Ethiopian banks by looking at valuation bases and their corresponding approaches. To meet this objective the researchers adopted a qualitative research approach where primary data were collected using key informant interviews from experienced valuers at four Ethiopian banks. The collected data were analysed and interpreted using clustering and the data were categorised into relevant themes. The study found that banks undertake mortgage valuation without any valuation basis, and they consider the cost approach as the only recognised valuation approach. Moreover, property valuers do not have sufficient professional competence in valuation and have no discretion to choose the appropriate valuation approaches. Based on the findings of this research, it is suggested that banks apply market value as a basis of valuation. The market value basis is compatible with the property market context of Ethiopia and international practices. The constitution of Ethiopia also supports it. Furthermore, banks should also adopt either the income, market or cost approaches depending on the nature and type of properties. But the cost approach can be applied as a check and balance on the reasonableness of the value determined using another approach and in cases where the two approaches are inappropriate. Valuers should also be able to use their discretion in selecting valuation approaches. These can be realised by establishing an independent national institution responsible for valuation regulation and certification.
\end{abstract}

Keywords: Valuation Bases; Valuation Approaches; Mortgage Valuation; Ethiopia 


\section{Introduction}

In many countries a significant part of investment in real estate is carried out through secured lending where real property is taken as a collateral security (Kalynichenko, 2017). An extensive study by Nguyen and Qian (2012) which examined data from 43 countries indicated that $73 \%$ of loans from financial institutions required collateral. The major concern of lenders while advancing credit is how they will get their money back and this implies that the engagement between lenders and borrowers is accompanied by a certain level of risk (Karumba \& Wafula, 2012). Due to this risk, borrowers assure the performance of their obligation by offering security on their property, charging the debt primarily on the property (Foote \& Murphy, 2007). The valuation of mortgaged security is therefore an important part of the mortgage lending process both at the commencement of the loan and during the life of the loan (RICS, 2018). To this end, it is an important endeavor to determine the degree by which the value of an asset exceeds the loan in providing the margin of asset cover and to increase the certainty that the asset being taken as a guarantee will cover losses in the case of loan default (EMF, 2009; Babawale, 2012; Udoekanem, 2017). Therefore, if valuation is accurate, borrowers would be encouraged to base their investment decision on the estimated value (Aliyu, 2017). On the contrary, inaccurate valuation erodes confidence in the operation of the property market. It could also lead to misallocation of resources and distortions in the property market in the longrun (Adegoke, 2016). To get appropriate valuation results, the valuation of properties should be supported by a recognised basis of valuation (TEGoVA, 2016). This is because the valuation basis guides the valuation result (Crosby $\&$ Hughes, 2011). Moreover, the valuation basis must be appropriate for the purpose of valuation since the basis of value may influence or dictate valuers' selection of valuation approaches, inputs and assumptions and the ultimate outcome of the valuation exercise (IVSC, 2017). For mortgage valuation, market value is the appropriate basis although there are circumstances which may require other bases (Crosby \& Hughes, 2011; Bowcock, 2015; RICS, 2017a). The income, market and cost approaches of valuation may provide market value, but the selection process considers the appropriate basis of value, respective strength and weakness of each approach, the nature of the asset and the availability of reliable information needed to apply the approach (IVSC, 2017).

In Ethiopia there is no valuation framework stating the bases and approaches of mortgage valuations. There is also no national regulatory institution responsible for valuation. As a result, there is a possibility that banks may manipulate valuation exercises to suit their institutional interest, for instance by under-valuing a property. This means due to the absence of valuation framework, regulatory institution and qualified external valuers, banks may value properties in a way that satisfies the banks' need only, while valuation considers the interests of both parties. This contradicts the mortgage valuation practice in many countries in which mortgage securities are valued based on national or international valuation standards by certified valuers (Adair et al., 2003). In the absence of valuation framework, there is also a possibility of inaccurate opinions of value estimates which has significant consequences. 
For instance, if the mortgaged property is undervalued, firms or household's investment potential is meaningfully affected. This is because the value of the property determines the loan amount (Aluko, 2007). On the other hand, if the mortgaged property is overvalued, banks may not be able to adeqauetly recover their loan in the case of default.

Due to the above, there is a need for a real property valuation framework stating the bases and approaches of valuation that is compatible to the real property market of Ethiopia. However, there is a severe lack of research on mortgage valuation that could support the development of such a framework. In order to start defining a framework for property valuation in Ethiopia, a logical starting point would be to gain an understanding of the various mortgage valuation practices that are currently employed by financial institutions in the country. The valuation basis and approach used by valuers should form the central aspect of any guiding framework for real estate valuation. Therefore, this paper aims to examine the bases and approaches of mortgage valuation in commercial banks in Ethiopia. Based on the findings, appropriate bases and approaches that could be part of the framework is suggested. To achieve this objective, a qualitative research approach was used. The research was based on primary data collected from four experienced bank valuers from four of Ethiopia's main commercial banks. The valuers were selected purposively based on their valuation experience. The collected data were analysed by clustering the data into themes.

Mortgage valuation plays a crucial role in the overall financial system (Oyedeji \& Sodiya, 2016). Its reliability and accuracy are therefore critically important for borrowers, financial institutions and other stakeholders. For borrowers, it is a guarantee for accessing finance since credit is often provided based on the value of a property. For financial institutions, it reduces the risk in the case of a loan default. Therefore, this study is important as it will contribute to the development of a valuation framework for Ethiopia that is coherent and makes use of the most appropriate mortgage valuation bases and approaches.

The paper is structured into five parts. The second part of the paper reviews the existing literature pertaining to mortgage valuation, the various processes relating to valuation and how the practice of mortgage valuation is carried out in Ethiopia. The third part of the paper provides an outline of the methodological approach adopted for this study. This is followed by the findings section which presents the data, analysis of the findings and provides a discussion of the findings. Finally, the fifth part of the paper provides a brief summary of the study and puts forward some implications of this research.

\section{Literature Review}

\subsection{Valuation Basis}

"Basis of valuation is a statement of the fundamental terms upon which a hypothetical exchange is assumed to take place" (RICS, 2008: 1). The valuation basis describes the nature of the assumed transaction, the 
relationship and motivation of the parties and the extent to which the asset is exposed to the market (RICS, 2008). It is an important premise on which the reported value of an asset is established (IVSC, 2017). On the other hand, the "valuation approach is the fundamental way in which, considering the available evidence, the valuer considers how to determine the value of the subject property" (TEGoVA, 2016,: 310). Sometimes, the valuation basis and valuation approach are taken as the same, but the latter is the way to reach specific values depending on the chosen valuation basis (RICS, 2008; IVSC, 2013; TEGoVA, 2016). It means the basis of valuation guides the result of valuation and not vice versa (Crosby \& Hughes, 2011). As a result, the valuation assignment for any purpose should be supported by a recognised basis of valuation (TEGoVA, 2016). The common valuation bases in the valuation literature are market value (MV), mortgage lending value (MLV), investment value (IV), and fair value (FV) (see Table 1). However, they are not mutually exclusive (RICS, 2008). For instance, in active real estate markets the market value of the property may be the same as the investment value or the fair value (Frics, 2019). For mortgage valuation, MV and MLV are usually applied (Bienert \& Brunauer, 2007; TEGoVA, 2016). However, the use of MLV is restricted in Europe since it has recognition in the EU regulation (TEGoVA, 2016). A brief description of the two bases (MV and MLV) are described in the subsections followed.

Table 1. Comparison of the Typical Valuation Bases

\begin{tabular}{|c|c|c|c|}
\hline $\begin{array}{l}\text { Basis of } \\
\text { Valuation }\end{array}$ & Description & Advantage & Limitations \\
\hline $\begin{array}{l}\text { Market } \\
\text { Value } \\
\text { (MV) }\end{array}$ & $\begin{array}{l}\text { Most probable price that } \\
\text { would be achieved in a } \\
\text { hypothetical exchange } \\
\text { in a free and open } \\
\text { market. }\end{array}$ & $\begin{array}{l}\text { Provides objective results, } \\
\text { it conforms to value in } \\
\text { exchange, accurate in } \\
\text { most markets. }\end{array}$ & $\begin{array}{c}\text { Tracks bubbles, } \\
\text { provides a snapshot } \\
\text { value at the valuation } \\
\text { date. }\end{array}$ \\
\hline $\begin{array}{l}\text { Mortgage } \\
\text { Lending } \\
\text { Value } \\
(\mathrm{MLV})\end{array}$ & $\begin{array}{l}\text { It is a value at risk } \\
\text { approach to manage the } \\
\text { risk exposure of credit } \\
\text { institutions taking into } \\
\text { account special safety } \\
\text { requirements. }\end{array}$ & $\begin{array}{c}\text { Provides long-term } \\
\text { sustainable value, does } \\
\text { not track price bubbles. }\end{array}$ & $\begin{array}{l}\text { It is subjective, does } \\
\text { not confirm to any } \\
\text { known economic } \\
\text { concepts of value, } \\
\text { requires high-level of } \\
\text { valuation skill. }\end{array}$ \\
\hline $\begin{array}{l}\text { Investment } \\
\text { Value (IV) }\end{array}$ & $\begin{array}{l}\text { Indicates the benefits } \\
\text { that a person or an entity } \\
\text { enjoys from ownership } \\
\text { of an asset. }\end{array}$ & $\begin{array}{l}\text { It conforms to value in } \\
\text { use and is a better } \\
\text { measurement for } \\
\text { investment decisions. }\end{array}$ & $\begin{array}{c}\text { Provides a snapshot } \\
\text { value at the valuation } \\
\text { date, there are various } \\
\text { investment values for } \\
\text { a property, it is } \\
\text { subjective. }\end{array}$ \\
\hline
\end{tabular}




\begin{tabular}{|c|c|c|c|}
\hline $\begin{array}{l}\text { Fair Value } \\
\text { (FV) }\end{array}$ & $\begin{array}{l}\text { Indicates the price that } \\
\text { would be reasonably } \\
\text { agreed between two } \\
\text { specific parties from the } \\
\text { exchange of an asset. }\end{array}$ & $\begin{array}{l}\text { It measures and reports } \\
\text { assets and liabilities on } \\
\text { the basis of their actual or } \\
\text { estimated prices. }\end{array}$ & $\begin{array}{l}\text { The asset is not } \\
\text { necessarily exposed } \\
\text { to the wider market. }\end{array}$ \\
\hline
\end{tabular}

\subsubsection{Market Value (MV)}

In most cases, the basis of mortgage valuation is market value (MV). MV is recognised as a typical valuation basis for mortgage valuation in the International Valuation Standard (IVS) and other regional and national valuation standards including the Royal Institution of Chartered Surveyors (RICS), The European Group of Valuers' Association (TEGoVA), (RICS, 2008; IVSC, 2013; TEGoVA, 2016). It has a long-established definition in the valuation literature where:

"It is the estimated amount for which the property should exchange on the date of valuation between a willing buyer and a willing seller in an arm's length transaction after proper marketing where in the parties had each acted knowledgeably, prudently and without being under compulsion"

(IVSC, 2017:18)

It is the main valuation basis for mortgage valuation in both established and emerging economies including Brazil, UK, Nigeria, Kenya and US (Aluko, 2007; Babawal \& Omirin, 2012; RICS, 2017b). It is also most widely implemented in Anglo-American countries (Bienert \& Brunauer, 2007) and in many European countries (Adair et al., 2003). MV as a basis of value is therefore compatible in cross-border financing activities (Bienert \& Brunauer, 2007). The supremacy of MV as a basis of value is due to its objectivity; it is not subject to different interpretations (Crosby \& Hughes, 2011).

Although MV is considered to be the most appropriate basis of mortgage valuation, some studies comment its shortcomings in certain circumstances. For instance, Lind (1998) argues the concept of MV is difficult to apply for unique and complex properties in 'thin' markets. The market evidence in such cases might be so weak, and the implications of competing theories so different, that an expert might not even be prepared to make a statement about the MV. Crosby et al. (2000) argue that MV does not last beyond the date of valuation and it gives no information regarding events during the timeframe of the loan in the future. Moreover, Crosby and Hughes (2011) also claim its inadequacy as it goes hand-in-hand with increased bank lending and inflated prices during an economic crisis. In cases where MV is unsuitable the application of other valuation bases is suggested. Valuation bases that are suggested to provide lenders with tools for more informed and prudent in such circumstances are IV and MLV (Crosby \& Hughes, 2011; Bowcock, 2015; RICS, 2017a). 


\subsubsection{Mortgage Lending Value}

"MLV is the value of immovable property as determined by a prudent assessment of the future marketability of the property taking into account long-term sustainable aspects of the property, the normal and local market conditions, the current use and alternative appropriate uses of the property"

(TEGoVA, 2016:42)

MLV is based on sustainability, avoidance of any speculation, traceability, standardisation and marketability (Bienert \& Brunauer, 2007). It takes into account the future value of the mortgaged property in that, among other things, it can be applied through the entire period of the loan (Gordon, 2015). In stable markets MLV and MV are indistinguishable (TEGoVA, 2016). However, in volatile markets there is a marked difference between the two bases. However, there is no simple enduring ratio between the two (TEGoVA, 2016). Moreover, MV and MLV have significant differences during instances of economic crisis. MV goes hand-in-hand with increased bank lending and inflated property prices (Crosby \& Hughes, 2011), while MLV provides sustainable value for a longer period of time (TEGoVA, 2016) (see Figure 1). MLV as a basis of value is recognised in Europe under the European capital requirement regulation (CRR) (TEGoVA, 2016). This is supported by a study by Bienert and Brunauer (2007), who found that in Germany and German speaking countries it is the dominant basis.

MLV does not have its own economic basis (it is neither value in exchange nor value in use) to apply, it is rather based on the concept of MV (Crosby \& Hughes, 2011). Thus, it is incapable of giving objective valuation outcomes because of the different interpretations which can be applied to each element of its definition (Crosby et al., 2000). However, Crosby and Hughes (2011) argue the possibility of adopting and applying it by preparing workshop manuals with a required set of inputs based on consistent schedules of data and rule of thumb adjustments. Although MLV is applied in Europe, it is not standardised or recognised by the IVSC.

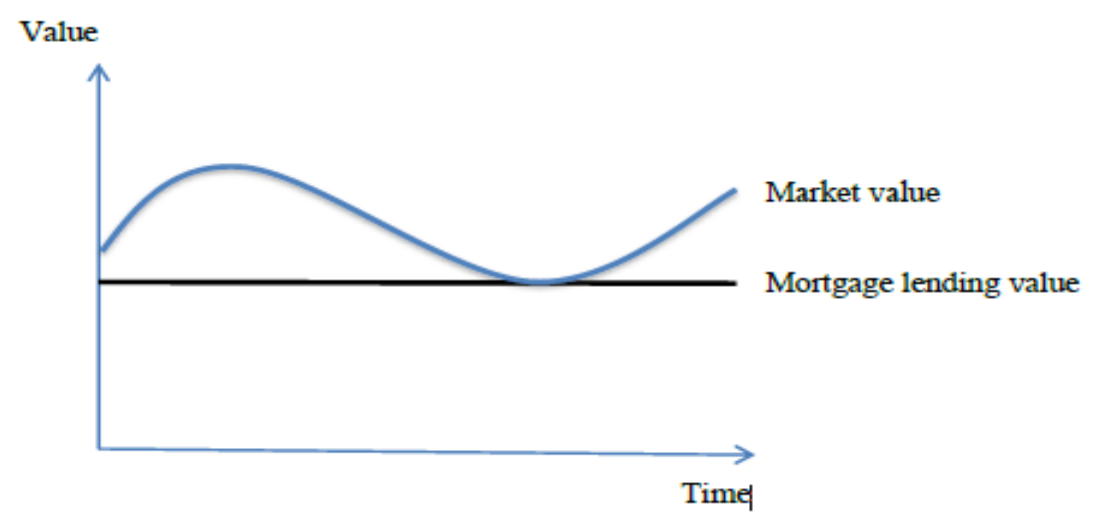

Figure 1. MV and MLV in Times of Economic Crisis

Source: (Anop, 2015) 


\subsection{Valuation Approaches}

The valuation approach is the way to reach specific values depending on the chosen valuation basis by considering the available evidence (RICS, 2008; IVSC, 2013; TEGoVA, 2016). Sometimes it is assumed that valuation approaches are similar to valuation basis. But valuation bases are the fundamental premises on which the reported values are based (IVSC, 2017). Valuations are required for different interests in various types of assets for different purposes. Therefore, the valuation approach in one case may well be inappropriate in another and so on, over time (RICS, 2017b). As a result, three conventional valuation approaches are recognised in the valuation literature. These are market approach, cost approach and income approach (TEGoVA, 2016; IVSC, 2017). These valuation approaches may be suitable to mortgage valuation, if based on appropriately analysed market-derived data (IVSC, 2017). The theoretical basis of these approaches dates back to 1920 when Alfred Marshall combined the supply-cost theory with demandprice theory as a basis of value (Moore, 2014). The market, income and cost approaches are based on the economic principles of price equilibrium, anticipation of benefits and substitution respectively (IVSC, 2017). The market approach assumes the value of the real estate is based on the views of the typical buyer and seller of the property (Miller \& Geltner, 2004). The income approach assumes the value of property is based on the typical investor's yield requirements, current financing possibilities, and the property risks (Miller \& Geltner, 2004). Market approach, on the other hand, is based on comparing the subject property with other identical or similar assets for which price information is available (Parker, 2016). Under the income approach, the value of an asset is determined by reference to the value of income, cash flow or cost savings generated by the asset (IVSC, 2017). Conversely, the cost approach assumes the value of the property is inherent in the cost to create the property based on land acquisition and building cost less wear and tear and depreciation (Miller \& Geltner, 2004). Therefore, the value of the property in this approach is determined by considering the market value of the site and the improvements separately, and then adding them (Adetiloye \& Eke, 2014).

Like valuation bases discussed above, valuation approaches are not mutually exclusive and one can use more than one approach for cross-verificationwhich is strongly encouraged, particularly where valuation inputs are limited (Parker, 2016). In cases where the valuer has a high degree of confidence in the accuracy and reliability of a single approach, they are not required to use more than one approach of valuation (IVSC, 2017). Theoretically, all the three approaches may be used for developing and supporting an indication of value for mortgage purposes. However, the replacement cost approach is largely considered to be unsuitable for mortgage since mortgage is an investment in the market and it lacks the capacity to reflect the fundamentals of investment uncertainty for mortgages (Aluko, 2007; Aro-Gordon, 2015). However, it can be used when there is no comparable property transaction in the market or when it is difficult to get definite income for the subject property (IVSC, 2017). Thus, the cost approach is mostly used as a check on the reasonableness of the value determined using another valuation approach 
(Aluko, 2007; IVSC, 2017). This is because the cost approach is based on the perception that the value of the property is inherent in the cost of creating the property (Miller \& Geltner, 2004). It is however, suitable for the valuation of specialised properties that have insufficient evidence to use the two approaches (Mooya, 2016). Such a specialised property where the cost approach might be used occurs when there is no transaction evidence or evidence of recent sales transactions (Adair et al., 2003; RICS, 2017a). In using the cost approach the valuer should have a good knowledge of construction costs or unit rates of construction (Onyejiaka et al., 2015).

The market approach is the most widely used and accepted to determine value for various purposes, including mortgage valuation. However, results will depend on the talent of the valuer to find reliable adjustment factors (Schulz, 2003). When a valuer's judgment is applied consistently, it may be both logical and rational; leading to an assessment of value that is transparently supported (Parker, 2016). The income approach is appropriate in cases where yields can be established easily (TEGoVA, 2016). Both the market and income approaches are the most recommended approaches for mortgage valuation (Aluko, 2007). In this regard, Aro-Gordon (2015) argued that using the income approach for the purposes of mortgage valuation is compelling, not discretionary. However, in selecting the approaches, the valuer is responsible, depending on their knowledge and experience (without neglecting the countries' legal framework), for choosing which approach to deploy in carrying out the valuation (Mohamad et al., 2015). In many European countries, including: Finland, France, Norway, Sweden and the UK, cost approach is used only for specialised properties (Adair et al., 2003; RICS, 2017a). In other European countries like Germany, Switzerland, Spain, Belgium and Portugal, cost approach is more widely used. However, it is usually used in tandem with other approaches, with the valuation being a weighted average of the two outcomes (Adair et al., 2003). In Nigeria it is used commonly for mortgage lending purpose (Aluko, 2007; Chukwuemeka \& Osmond, 2014). The reason for its use in the Nigerian context is due to the challenges of getting appropriate yield rates in the market (Chukwuemeka \& Osmond, 2014).

\subsection{Mortgage Evaluation in Ethiopia}

Modern banking in Ethiopia started in the beginning of the 20th century since the establishment of the bank of Abyssnia in 1906 (Seyoum \& Bessie, 2018). The provision of mortgage loans has been one of the main functions of commercial banks in Ethiopia. But there is no well-known empirical study on how mortgage valuation in Ethiopia is practiced. Presently, there is no mortgage valuation framework or regulatory institution to oversee mortgage valuation. The national bank of Ethiopia (NBE); which has the power to license, supervise and regulate the operations of commercial banks, does not have a clear policy concerning mortgage valuation. It simply forces banks to undertake valuations without any guideline or framework (NBE, 2010). Moreover, the responsible ministry for urban land administration and management in Ethiopia, the Ministry of Urban Development and Construction, does not have any power and duty in mortgage valuation 
(FDRE, 2018). According to a newspaper article by Getachew (2017), the Ethiopian bankers' association has prepared and distributed a real property valuation manual to banks to apply similar procedures of mortgage valuation to all banks in 2014 . However, the actual mortgage valuation practice still lacks uniformity and consistency.

Commercial banks in Ethiopia recognise the cost approach as the suitable mortgage valuation approach to the Ethiopian real estate market. For instance, the valuation manual of the Commercial Bank of Ethiopia (CBE) states that it adopts the cost approach due to its suitability for the property market in terms of availability of relevant comparative databases in Ethiopia (CBE, 2016). However, as highlighted by the literature above this approach of valuation is largely seen as unsuitable for mortgage valuations. The credit policy of the bank on the other hand, stipulates that the bank may use either of the three approaches as they see appropriate (CBE, 2013). The valuation manual of Dashen Bank also states that the bank adopts a combination of the cost approach and income approach. This combination is said to help them cope with varying market values (Dashen_Bank, 2014).

It is thus clear that in the absence of any guiding framework, there is no consistency in the way in which mortgage valuation is carried out by banks in Ethiopia. Developing a guiding framework is necessary to providing reliable and accurate valuations. This has significant economic benefits for various parties and is central to a functioning and efficient real estate market. Such a framework should seek to align international standards with the established skills and practices of valuation practitioners in Ethiopia. Therefore, to help define a framework for mortgage valuation it is necessary to understand the various valuation practices, particularly the bases and approaches of valuation adopted by banks in Ethiopia. This is the main focus of this study. The methodological approach is outlined below.

\section{Methodology}

In Ethiopia, there is no theoretical and empirical literature pertaining to mortgage valuation. Despite the fact that mortgage valuation is important for economic development, it is surprising that no empirical research has been conducted on this topic. As a result, the researchers believe that this paper is the first and can become a base for further studies.

The study followed a qualitative research approach where the researchers seek to understand the phenomenon from experienced valuers from selected commercial banks in Ethiopia (Yegidis et al., 2011). The target population is all 17 commercial banks which provide mortgage credit for households and firms. The study employed semi-structured interviews for the primary sources of data. Secondary data was collected from valuation laws, national and international valuation standards, reports, valuation manuals, credit policy documents, books and other empirical works. The reason for undertaking interviews was to get more information in greater depth and to get an opportunity to restructure questions based on the reaction of the interviewees. The collected data were analysed and interpreted using clustering and 
categorising the data into relevant themes. Banks in Ethiopia use similar procedures of mortgage valuation where they adopt the working manual from the most experienced bank; the Commercial Bank of Ethiopia (CBE). Four banks were selected purposively based on their banking experience. Accordingly, the Commercial Bank of Ethiopia, Awash Bank, Dashen Bank and Abay Bank were selected. The number of valuers in each bank is few and they depend on the valuation manuals prepared by the bank. As a result, one valuer from each bank is supposed to be able to provide adequate information. So, from each bank one experienced valuer was selected. To increase the reliability of the information from the interviewees, the interviews were conducted by preparing similar standardised questions for the participants and were administered to them separately as suggested by Conway et al. (1995). The researcher carried out all of the interviews. All four of the selected valuers are qualified civil engineers with no formal valuation degrees. Before they were hired as valuers by the banks, they were employed as engineers in other sectors. However, the key informants were trained to perform valuations by their respective banks after they joined the bank and all of them have since acquired more than 5 years of work experience in mortgage valuation.

Concerning the background of sampled banks, CBE is a state-owned bank established in August 1942. The bank has an asset value of ETB 711.96 billion (USD 24.6 billion) as of June 30, 2019. Today it has nearly 1,500 branches across the country with more than 37,000 permanent employees and more than 22,000 outsourced jobs (CBE, 2020). The bank dominates the financial market in terms of assets, deposits, bank branches and total banking work force. Awash Bank is the first private bank in Ethiopia established in February 1995. Its total assets reached ETB 74.6 billion (USD 2.6 billion) as of June 30, 2019. It has over 430 branches (Awash Bank, 2019). Dashen Bank was established in January 1996. The bank has total assets of ETB 56.2 billion (USD 1.94 billion) as of July 2019. It has a total number of 413 branches. The bank has 6,129 permanent and 3,604 outsourced employees (Dashen Bank, 2019). Finally, Abay bank started operating in November 2010. The bank's asset worth is ETB 15 billion (USD 516.6 million) as of June 30, 2019. Today the bank has over 220 branches (Abay Bank, 2019).

\section{Findings and Discussion}

In Ethiopia there is no valuation framework, regulatory institutions and professional valuation firms. As a result, commercial banks undertake mortgage valuation without basis although MV is appropriate. Commercial banks adhere to the cost approach for all types of mortgage securities. In using the cost approach, the way of estimating depreciation and land value is not scientific. This may be due to the fact that valuers in banks are engineers without valuation degrees. The mortgage valuation system in Ethiopia contradicts the valuation practice in many countries where reliable valuation results can be produced only by a valuation professional that adheres to international standards and professional practice (Babawal \& Omirin, 2012; Parker, 2016; TEGoVA, 2016). In the following subsections the bases and approaches of valuation implemented in Ethiopian banks is discussed. Based 
on the discussion, an appropriate basis and approaches of mortgage valuation is suggested.

\subsection{Basis of Valuation Implemented in Banks}

The basis of valuation is an important determinant of value where it dictates the entire valuation result (Crosby \& Hughes, 2011). TEGoVA (2016) recommends that valuation assignments for any purpose should be supported by a recognised basis of valuation. However, in Ethiopia there is no specific mortgage valuation framework or independent institution that outlines the use of a valuation basis. As a result, it is argued that banks undertake mortgage valuation depending on institutional interests without valuation basis. Hence, valuation practices in Ethiopia do not adequately consider the interests of both parties, and banks act in their own best interest and the expense of potential borrowers. A research respondent explained that the main purpose of valuations by banks is not to estimate the market value of properties, but rather to ensure the banks can get their money back in case of default. In this case the amount of loan given to borrowers is not based on the value of the property but on securing the bank from risk as much as possible. Thus, properties are routinely under-valued which limits the borrowing potential of households and businesses using properties as collateral to secure a loan. This may have a significant effect on the investment and financing potential of borrowers. Although the interviewed valuers claimed that valuations follow a specific valuation basis, there is a number of valuation bases used in the mortgage valuation system of banks. Three valuers explained the basis of valuation adopted is replacement while another valuer claimed they adopted $\mathrm{MV}$ as their valuation basis. But there is no valuation basis called replacement cost in the valuation literature and replacement cost/cost approach is in fact a valuation method.

The argument of replacement cost as a recognised basis by valuers is not strange, since valuers in mortgage valuation are engineers who do not have valuation degrees. The respondents also confirmed that other valuers employed in banks in Ethiopia are civil engineers too. Naturally, civil engineers may be good in determining the cost of production for buildings, but they may not be familiar with market value concepts. So, from engineers without valuation degrees, reliable and accurate valuation may not be expected. Moreover, valuers explicitly depend on the valuation guidelines for the entire valuation. The guidelines describe how valuation is done using the cost approach. The valuation guideline may influence valuer's perception about the valuation basis. As a result, they may assume that cost replacement is a basis of valuation, which was the case for the interviewed valuers. Again, this alludes to the possibility that the valuers are not properly trained in the exercise they have been tasked with. The absence of a valuation basis may also be the result of there being no valuation standard or valuation framework in the real property valuation system. This is because valuation bases can be obtained from either valuation standards or defined by statute, regulation or other documents (IVSC, 2013). The practice of valuation in banks is also against the suggestion by TEGoVA (2016), which states that valuation assignments should be carried out in accordance with the national or 
international valuation standards, by knowledgeable, skilled and experienced valuers under the strict supervision of a qualified valuer.

In the absence of a valuation basis banks estimate the mortgage security depending on their interests as suggested above. Due to the lack of formal training on mortgage valuation, there is also a possibility of valuers producing a wrong opinion of value. This can cause confusion and misunderstanding among users and experts of valuation which decreases the investment potential of households and firms (Aro-Gordon, 2015).

\subsection{Valuation Approaches Practiced in Banks}

Interviews conducted on commercial banks revealed that they undertake mortgage valuation using the cost approach independent of the type and nature of properties. This was confirmed by all the interviewed valuers. Although the valuation manuals and credit policies of banks stipulate the use of income and market approaches, valuers claim this is not the case in actual practice. Valuers also argued that the cost approach is adopted due to its suitability to the property market in terms of availability of relevant comparative data, the difficulty in updating rental rates of buildings, and the lack of stability in the Ethiopian property market. This contradicts the literature where the income approach is the most appropriate for mortgage valuation in these contexts (Aluko, 2007). Further, it is questioned whether the valuers (who are engineers and are unlikely to have expert insight into property markets) have sufficient knowledge and experience to claim that the cost approach is the most appropriate.

According to interviewed valuers, if the relevant data required to use market and income approaches is obtained, they are not applicable since the Federal Democratic Republic of Ethiopia (FDRE) constitution prohibits land as being mortgaged. The valuers' argument stems from article 40 sub article 3 of the constitution which states that the right to ownership of land is exclusively vested in the state and in the peoples of Ethiopia (FDRE, 1995). From this, valuers perceive that property owners are granted the right to improvements on the land, but are not given ownership rights to the land itself. However, the same article of the constitution provides joint ownership of land to the state and nations, nationalities and peoples of Ethiopia (FDRE, 1995). This indicates that the economic value of land is shared between the state and property owners. Although valuers argued land is not qualified as a mortgage security, they also include location value in property valuation by assuming land value and location value are different. The researcher argues that it is irrational to assume land value and location value are different where land value is the contribution of location in terms of accessibility and availability of infrastructure (LILP, 2016).

Regarding sales of real properties, the market approach is practiced in Ethiopia. One valuer contends that the actual transaction price of real property in cities does not indicate market value since it is higher due to the role of brokers in the transaction. Another valuer supports this statement by explaining that actual sales price in urban Ethiopia has skyrocketed due to the 
role of brokers. The interviewed valuer further believes that the direct sales price of real properties does not indicate the actual market value. It is true that brokers have a significant role in property sales in Ethiopia, but their role is limited in searching for potential properties in the market and simplifying the process of buying and selling. Brokers may suggest the price of the property based on their understanding of the property market, however, it is a suggestion and not a valuation. The final sales price of properties is agreed between the seller and buyer and they may accept the suggestion of brokers or not. This is an indication that the sales price of properties is based on the open market. But valuers are disregarding the market approach as a scientific and appropriate strategy for mortgage valuation. The valuers argument also contradicts current mainstream theories of value which is based on the neoclassical theory of value which claims value is determined by the intersection of demand and supply (Jaffe \& Lusht, 2003).

Estimating the market value using the cost approach involves carrying out the following process: estimating the value of the site as though it is vacant; estimating the cost to produce the improvements, subtracting depreciation, and finally adding the site value at its highest and best use (Adetiloye \& Eke, 2014). Since the land of the subject property is already developed, the valuer has to estimate the land value by using the market approach while the cost of building a structure with identical characteristics is valued by first calculating the replacement cost of a new structure, and second by downward adjustments due to physical or functional deterioration (Schulz, 2003). Banks in Ethiopia estimate property value by adding building value and land value. The specific procedures of estimation of building and land is presented in the subsections followed.

\subsubsection{Building Estimation}

According to the interviewed valuers, banks undertake building valuations using a bill of quantities and the square metre methods. The bill of quantities method is used for calculating the project cost of a building under construction or for newly constructed buildings, while the square metre method is used for estimating the cost of buildings where construction is completed. Estimation of building costs by a bill of quantities calculates the price of each physical item of the building in the market and adds the indirect costs related to the construction. Under the square metre method, the size of the building (in $\mathrm{m}_{2}$ ) is multiplied by a rate per-square metre to get to a value for the construction cost. For both types of ratings, unit cost rates are given in the valuation manuals of banks even if the unit rate varies among banks. The unit rate for the building is based on the building grade which considers the quality of buildings. The unit cost rates are given as ranges of values to allow the valuer to employ his/her expert judgment for the intrinsic features of the specific property. When looking at a glance, the way of estimation of building value seems rational. This is because unit cost rates are prepared based on the type of construction materials used. But banks do not take the unit cost rates from reliable sources such as responsible government institutions; including municipalities, the Ministry of Urban Development and the Central Statistics Authority. It might be due to the lack of a 
standardised valuation system and the absence of a legal framework for mortgage valuation. The researchers argue that if banks take arbitrary unit cost rates by themselves, the value of the building could rely on a nonscientific value which is likely to misrepresent the value of a given property.

In valuations using the cost approach, depreciation adjustments are considered for the wear and tear of the building from different sources (IVSC, 2017). Typically, there are three causes of depreciation of a building. These are physical deterioration, functional obsolescence and economic obsolescence (Onyejiaka et al., 2015). The responses from interviewed valuers indicates that depreciation is most commonly calculated by considering the physical condition of the property (physical deterioration). This suggests that banks typically do not consider the loss in utility and value due to a reduction in the desirability of the property (functional obsolescence) and a loss in value caused by negative influences outside of the subject property that are generally beyond the control of the subject property owner (external obsolescence). Without considering the appropriate depreciation causes it makes it difficult to reach an accurate building value. It is suggested that this also links back to the lack of formal training of the valuers who may lack the necessary skills and insight to make interpretations about properties or real estate markets that go beyond merely calculating values.

\subsubsection{Land Valuation}

In Ethiopia, urban land is governed by a lease system 1 . However, there are also plots of land legally acquired before the urban centres entered into the lease system. These are called 'old possession' plots and are treated differently. Although the market approach is common for land value estimation, there are also other methods, including the allocation and the development methods (Appraisal Institute, 2013). According to the interviewed valuers, the methods of land valuation adopted by banks is not from the recognised methods but is rather based on the unit price rate of land prepared by each bank. The comprehensive list of the unit price rates of each neighbourhood in each city is described in the valuation manual of the banks. Valuers claim that the unit price rate is developed by an in-depth study of the market depending on the rank of cities/towns and the land grade of a specific city. However, in practice the unit price rate of land is determined by very simplistic methods; the distance from a main road. Other land value determinant factors are not incorporated.

In summary, using the cost replacement approach of valuation is inadequate in reflecting marketability of a mortgaged property, it is typically used for assets that have no comparable properties, sales or rental transaction evidence, but where current construction cost rates are available (AroGordon, 2015). It also contradicts the literature where the income approach is largely considered the most appropriate for mortgage valuation (Aluko, 2007). However, adopting the cost approach for every property is not compatible to the existing tenure system of urban Ethiopia. This is because 
real properties in Ethiopia are sold and purchased on the open market. The researcher believes the actual transaction price can provide a rational value rather than simply taking the cost of production and an arbitrary land value. In cases where the cost approach is suitable, the unit price rate of land and the cost rates of building is obtained from reliable publications. Moreover, the existing lease price can be taken as a rational value for land value estimation. This is because the lease price of land is based on competitive auction sale as stipulated under article 7 sub article 2 of the lease proclamation (FDRE, 2011). Moreover, the actual transferred plots in each neighbourhood can be obtained from municipalities. Thus, the way of valuation by banks is problematic in three primary ways. First, it adopts only one approach of valuation without considering the nature of the asset, the market condition and the availability of reliable information needed for accurate valuations. Second, the method of land value estimation and deprecation is not scientific. Third, the valuation assignment is carried out by engineers, who are unlikely to have the necessary insight and understanding of property markets to make accurate and reliable valuations.

\subsection{Market Value as an Appropriate Mortagage Valuation Basis for Ethiopia}

The appropriate basis of mortgage valuation in Ethiopia can be viewed from the property market context of Ethiopia, the international compatibility of the basis and the legal framework of Ethiopia. The MV approach is compatible with the property market context of Ethiopia. Though there is no mortgage valuation framework in Ethiopia, the FDRE constitution provides joint ownership of land to the state and peoples of Ethiopia. This enables property owners to mortgage their land, making MV an appropriate basis for this too. Alternatively, the MLV approach has the potential to be applied. However, this approach has challenges in Ethiopia because its calculations are dependent on a dynamic property market. In addition to this, the MLV approach requires that valuers have a good understanding of the property market and a high-level of property valuation skills. Moreover, it is exposed to different interpretations since it not grounded in any unique economic theory. Crosby and Hughes (2011) suggest the suitability of the MLV approach for banks if provided with a workshop manual. However, in Ethiopia getting the requisite capitalisation rates and professional and qualified valuers makes it difficult to adopt. In the following subsections the justifications of $\mathrm{MV}$ as an appropriate basis for mortgage valuation is explained.

\subsubsection{Property Market Context}

It is believed that the context of the property market influences the valuation basis (TEGoVA, 2016; IVSC, 2017). In Ethiopia, real property sales transactions are based on the market approach and brokers have a role in the sales price determination depending on their experience and observations in prior sales transactions. Although brokers possess a general tendency to inflate prices, with an overall intention of benefiting from the commission calculated as a percentage of the sales value, they are not the ones that fix price, as explained in the previous section. This means the sales price of 
properties is based on the interaction between demand and supply. According to the current mainstream theory of value, the sales price of properties explains the true value of properties (Jaffe \& Lusht, 2003). Therefore, for banks, considering the sales price is a rational option and should give preference over simply taking the cost of a building and an arbitrary land valuation.

In Ethiopia, the sales price of small houses in the center of cities are high due to their location and accessibility to various services. This is an indication that the value of land influences the total property price significantly (Asres, 2019). However, banks fail to consider this fact. Rather, they do not consider the appropriate value of land by arguing that land is not qualified as a mortgage as they believe all land to be owned by the state. According to Ambaye (2013), the estimated value of properties for mortgage lending by banks in Ethiopia is on average around $10-20 \%$ of the actual sale price. The difference between the sales value and the mortgage value of the property in this case is extremely large, and this raises the question of the rationality of the system. Therefore, banks in Ethiopia can use MV as a basis of mortgage valuation as it is actually practiced based on the sales transaction in the real estate market. Aluko (2007) also suggested that mortgage valuation should be done with the same principles of sales price. Policy makers in valuation should also consider the actual practice in the property market. This is because considering the actual practice is key for its success as it enables points of references to triangulate valuations (McAuslan, 1987). Parker (2016) also suggests that the valuation practice is strictly tied to practices and customs related to the economic activity of countries. Therefore, valuation practices should arise from (and be developed within) national contexts in relation to legislative, administrative and fiscal regulations, and more generally to the economic and social setting of a region.

The second justification of MV as an appropriate basis of mortgage valuation for the context of the Ethiopian property market is because of the accessibility of property data. There is a wealth of property-related data accruing from rental markets for both residential and commercial properties. Normally, market rent is used to indicate the amount for which a property may be let, or for which a let property may be re-let when the existing lease terminates (RICS, 2008). In Ethiopia, annual rental values have been used to determine the property tax since the imposition of the first property tax proclamation in 1945. Furthermore, renting is the main form of housing tenancy in Ethiopian cities. This means there is a possibility of getting suitable data from the rental market to make accurate valuations (Goodfellow, 2015). In this way the MV approach is an satisfactory candidate for mortgage valuation basis in Ethiopia.

\subsubsection{International Compatability}

Since the legal structure, economic development and socio-political context of countries vary, the choice of specific valuation bases, approaches, techniques and standards differ from country to country (Adair et al., 2003). However, the exponential growth of globalisation in business has reduced the significance of independent national property valuation standards (Parker, 
2016). Therefore, the standards of property valuations in various countries have to harmonise with each other, and to do that there must be a strong, single benchmark of common standards to which states can reference (Parker, 2016). This is because valuation is the foundation for lending decisions, financial reporting of multinational companies across border property investment, securitisation of real estate and so forth (Babawal \& Omirin, 2012). In this regard, international valuation standards and other national and regional standards adopt MV as an appropriate basis for mortgage valuation (RICS, 2008). Furthermore, it is the main valuation basis for mortgage valuation in both established and emerging economies including Brazil, UK, Nigeria, Kenya and US (Babawal \& Omirin, 2012; RICS, 2017b). Therefore, the basis of mortgage valuation can be adopted from international experience. In this regard MV can be also an appropriate basis for mortgage valuation in Ethiopia.

\subsubsection{Mortgaging Land Under the Constitution of the Federal Democratic Republic of Ethiopia}

In Ethiopia the FDRE Constitution is the supreme law that other laws must subscribe to. The constitution under article 40 sub article 3 recognises the joint ownership of land to nations, nationalities and peoples of Ethiopia and the state (FDRE, 1995). This indicates that the constitution does not prohibit land from being taken as a mortgage security. Nevertheless, valuers argued that land is not qualified as a mortgage security. However, they take into account land value in mortgage valuation assignments anyway, although to a much lower degree. The belief that land does not qualify as a mortgage security is a flawed understanding of valuation for a number of reasons. First, banks include land value in mortgage valuations by assuming land value and location value are different. But their assumption is not reasonable as discussed in section (see section 3.3). Further, the way of estimating land value is not standardised. Second, in sales and purchase transactions it is the land which is actually transacted (as discussed in section 4.3.2). If the constitution denied the economic value of land as valuers claim, property owners should only be able to sell the improvements or buildings. But, in practice they are selling the property. If we accept valuers' claims that land is not valid for mortgage security, a large percentage from the sales price in the case of sales transaction should be given to municipalities (since land is the property of the state, municipalities should take the share of the land value from the total price of the property). From this simple logic, one can understand the constitution does not prohibit the value of land to property owners.

\section{Conclusion}

This study examined mortgage valuation bases and approaches practiced by commercial banks in Ethiopia. The research findings revealed that banks undertake mortgage valuation without any consistent valuation basis. Moreover, banks adopt the cost approach as the only appropriate valuation approach for all mortgage securities. Banks persist with the cost approach even when conventional valuation practices require other approaches. The 
practice of valuation without a clear valuation basis and the blind use of the cost approach may be due to the absence of independent regulatory institution for mortgage valuation and an absence of a valuation framework. The employment of engineers without valuation degrees may also contribute to the haphazard manner in which mortgage valuation is practiced in Ethiopian banks. In Mortgage valuation practices administered by banks, valuers have no discretion on the selection of appropriate valuation approaches. In using the cost replacement approach, the way of estimating depreciation and land value are not logical or rational. First, the sources of depreciation from functional and economic obsolescence are not taken into account in the depreciation calculations. Second, valuers failed to adopt any recognised land value estimation techniques, rather they are based on arbitrary unit price of land. Third, valuers did not consider available sources of data for building and land value estimation from various government institutions. The outcome is that mortgage valuations lack any clear science, even when using a recognised valuation approach such as the cost approach.

The property valuation system in Ethiopia can be improved by creating an independent institution for valuation regulation and policy making. In designing real property valuation policy, the various contextual and practical settings on the ground should be considered so that the economic value of land is included in the mortgage valuation, among others. Furthermore, policy makers should develop property valuation standards which cover bases and approaches of valuation. In this regard, the appropriate basis for mortgage valuation for the real property market system of Ethiopia should be MV as it is compatible with international standards, it conforms to the constitution and the practices and market context of Ethiopia can support its implementation. The market and income approaches of valuation are also compatible to the MV basis. As a result, they can be applied predominantly, but the cost approach can be used as an alternative approach when data is insufficient in the market. In any case, the specific choice of the valuation approach should left for the judgment of the valuer who is expected to use their experience and knowledge of the real estate market to make the appropriate choice (within the given legal framework).

\section{References}

Abay Bank. (2019). Abay Bank Annual Financial Report for the Year 2018/19. Addis Ababa, Ethiopia: Abay Bank.

Adair, A., Downie, M.L., McGreal, S. \& Vos, G. (2003). European Valuation Practice: Theory and Techniques. London, UK: E \& FN Spon.

Adegoke, O.J. (2016). Effects of Valuation Variance and Inaccuracy on Nigerian Commercial Property Market an Empirical Study. Journal of Property Investment \&Finance, 34(3), pp.276-292. DOI: 10.1108/JPIF-08-2014-0056.

Adetiloye, K.A. \& Eke, P.O. (2014). A Review ofReal Estate Valuation and Optimal Pricing Techniques. Asian Economic and Financial Review, 4(12), pp.1878-1893. 
Aliyu, B.A. (2017). Factors Influencing Mortgage Valuation Inaccuracy of Residential Property Market within Kaduna Metropolis (Nigeria). Masters dissertation. Faculty of Geoinformation and Real Estate, Universiti Teknologi Malaysia.

Aluko, B.T. (2007). Implications of the Current Trend in Mortgage Valuation Practice in Nigeria. International Journalof Strategic Property Mnagement, 11(1), pp.17-31.

Ambaye, D.W. (2013). Land Rights and Expropriation in Ethiopia. PhD dissertation. Royal Institute of Technology (KTH), Sweden.

Anop, S. (2015). Comparison of Valuation and Lending Policies in Germany and Sweden. School of Architecture and the Built Environment (ABE), Royal Institute of technology (KTH), Sweden.

Appraisal Institute. (2013). The Appraisal of Real Estate (14th ed.). Chicago: American Institute of Real Estate Appraisers.

Aro-Gordon, S. (2015). Rethinking Valuation Methodology for Sustainable Mortgage Financing: A Nigerian Perspective. In proceedings of the International Conference on Global Economic Growth and Sustainability. Mysuru, India.

Asres, H.B. (2019). Real Property Valuation in Expropriation in Ethiopia; Bases, Approaches and Procedures. African Journal of Land Policy and Geospatial Sciences, 3(2), pp.40-51.

Awash Bank. (2019). Awash Bank Annual Financial Report of the Year 2018/19. Addis Ababa: Awash Bank.

Babawal, K.G. \& Omirin, M. (2012). An Assessment of the Relative Impact of Factors Influencing Inaccuracy in Valuation. International Journal of Housing Markets and Analysis, 5(2), pp.145-160. DOI: $10.1108 / 17538271211225904$.

Babawale, G.K. (2012). Valuers' Liability in Mortgage Valuation. Khazar Journal of Humanities and Social Sciences, 30(1), pp.49-55.

Bienert, S. \& Brunauer, W. (2007). The Mortgage Lending Value: Prospects for Development within Europe. Journal of Property Investment \& Finance, 25(6), pp.542-578. DOI: 10.1108/14635780710829289.

Bowcock, P. (2015). A Discussion Paper on Valuations for Mortgage and the Level of House Prices. International Journal of Housing Markets and Analysis, 8(1), pp.27-35. DOI: https://doi.org/10.1108/IJHMA-072014-0024.

CBE. (2013). Commercial Bank of Ethiopia Credit Process Procedure. Addis Ababa: Commercial Bank of Ethiopia.

CBE. (2016). Commercial Bank of Ethiopia Real Property Valuation Manual. Addis Ababa: Commercial Bank of Ethiopia.

CBE. (2020). Commercial Bank of Ethiopia Home Page. [Online]. Available at: $\quad$ http://www.combanketh.et/Aboutus/Companyprofile.Aspx Retrieved: March 14, 2020

Chukwuemeka, E. \& Osmond, I.C. (2014). Challenges of Mortgage Valuation in Port Harcourt, Nigeria. Issues in Business Management and Economics, 2(4), pp.74-79.

Conway, J.M., Jako, R.A. \& Goodman, D.F. (1995). A Meta-Analysis of Interrater and Internal Consistency Reliability of Selection Interviews. Journal of Applied Psychology, 80 (5), pp. 565-579. 
Creswell, J.W. (2014). Research Design: Qualitative, Quantitative and Mixed Methods Approaches (4th ed.). United States: SAGE Publications Ltd.

Crosby, N., French, N. \& Oughton, M. (2000). Bank Lending Valuations on Commercial Property. Does European Mortgage Lending Value Add Any Thing to the Process? Journal of Property Investment \& Finance, 18(1), pp.66-83.

Crosby, N. \& Hughes, C. (2011). The Basis of Valuations for Secured Commercial Property Lending in the Uk. Journal of European Real Estate Research, 4(3), pp.225-242.

DOI: $10.1108 / 17539261111183425$.

Dashen Bank. (2014). Dashen Bank Real Property Valuation Procedure Manual. Addis Ababa: Dashen Bank.

Dashen Bank. (2019). Dashen Bank Annual Financial Report for the Budget Year 2018/19. Addis Ababa: Dashen Bank

EMF. (2009). European Mortgage Federation Study on the Valuation of Property for Lending Purposes. Brusells: European Mortgage Federation (EMF).

FDRE. (1995). Constitution of the Federal Democratic Republic of Ethiopia, Proclamation Number1/1995. Addis Ababa: Federal Negarit Gazeta.

FDRE. (2011). Urban Lands Lease Holding Proclamation. Addis Ababa: Federal Negarit Gazeta.

FDRE. (2018). A Proclamation to Provide for the Definition of the Powers and Duties of the Excutive Organs of the Federal Democratic Republic of Ethiopia, Proclamation Number 1097/2018. Addis Ababa: Federal Negarit Gazette.

Foote, B.E. \& Murphy, E.V. (2007). Mortgages, Fundamentals, Issues and Perspectives. New York: Nova Science Publishers, Inc.

Getachew, G. (2017). Ethiopia: Bankers Association Issues Manual for Consistent Valuations, Addis Fortune.

Goodfellow, T. (2015). Taxing the Urban Boom: Property Taxation and Land Leasing in Kigali and Addis Ababa. Brighton: Institute of Development Studies.

Gordon, S.A. (2015). Rethinking Valuation Methodology for Sustainable Mortgage Financing: A Nigerian Perspective. In proceedings of the International Conference on Global Economic Growth and Sustainability : Challenges and Prospects. Mysuru, India.

IVSC. (2013). International Valuation Standards. London: International Valuation standard Council (IVSC).

IVSC. (2017). International Valuation Standards. London: International Valuation standard Council (IVSC)..

Jaffe, A.J. \& Lusht, K.M. (2003). The History of Value Theory. Research Issues in Real Estate, 9.

Kalynichenko. (2017). Methodological Principles for the Valuation of the Mortgage Real Estate. Technology Audit and Production Reserves, 6/5(38), pp.25-29.. DOI: 10.15587/2312-8372.2017.119668.

Karumba, M. \& Wafula, M. (2012). Collateral Lending: Are There Alternatives? Kenya Bankers Association: Centre for Research on Financial Markets and Policy. 
LILP. (2016). Land and the City. In proceedings of the 2014 Land Policy Conference. Cambridge, Massachusetts.

Lind, H. (1998). The Definition of Market Value: Criteria for Judging Proposed Definitions and an Analysis of Three Controversial Components. Journal of Property Valuation \& Investment, 16(2), pp.159-174.

McAuslan, P. (1987). Land Policy: A Framework for Analysis and Action. Journal of African Law, 31 (1/2), pp.185-206.

Miller, N.G. \& Geltner, D.M. (2004). Real Estate Principles for the New Economy. Journal of Real Estate Literature, 12(3).

Mohamad, J., Ismail, S., Abrhman, R. \& Ismail, A.R. (2015). Valuers' Perception on the Current Practice of Heritage Property Valuation in Malaysia. In proceedings of the Annual Pacific-Rim Real Estate Society Conference. Kuala Lampur, Malaysia.

Moore, J.W. (2014). A History of Appraisal Theory and Practice ; Looking Back from Iaao's 75th Year. Journal of Property Tax Assessment \& Administration, 6(3), pp.23-50.

Mooya, M.M. (2016). Real Estate Valuation Theory: A Critical Appraisal. Berlin: Springer.

NBE. (2010). Bank Risk Management Guidelines. Addis Ababa: National Bank of Ethiopia (NBE).

Nguyen, H. \& Qian, R. (2012). The Cross-Country Magnitude and Determinants of Collateral Borrowing. Policy Research Working Paper 6001. Washington, DC: The World Bank.

Nwuba, C.C., Egwuatu, U.S. \& Salawu, B.M. (2015). Clients' Means of Influence on Mortgage Valuation in Nigeria. Journal of Property Management, 33(4), pp.367-385. DOI: 10.1108/PM-03-2014-0016.

Onyejiaka, J.C., Oladejo, E.I. \& Emoh, F.I. (2015). Challenges of Using the Cost Method of Valuation in Valuation Practice: A Case Study of Selected Residential and Commercial Properties in Awka and Onitsha, Anambra State, Nigeria. International Journal of Civil Engineering, Construction and Estate Management, 3(2), pp.16-35.

Oyedeji, J.O. \& Sodiya, A.K. (2016). Forms of Mortgage Valuation Inaccuracies and Implication on Real Estate Development Finance in Nigeria. Covenant Journal of Research in the Built Environment (CJRBE), 4(1), pp.86-114.

Parker, D. (2016). International Valuation Standards: A Guide to the Valuation of Real Property Assets. Oxford: John Wiley \& Sons, Ltd.

RICS. (2008). Valuation Standrd 6th Edition (6th ed.). Royal Institution of Chartered Surveyors: London.

RICS. (2017a). Valuation: Global Standards 2017 Uk National Supplement. Royal Institution of Chartered Surveyors: London.

RICS. (2017b). Valuation Global Standards:Incorporating the International Valuation Standards. Royal Institution of Chartered Surveyors: London.

RICS. (2018). Bank Lending Valuations and Mortgage Lending Value. Royal Institution of Chartered Surveyors: London.

Schulz, R. (2003). Valuation of Properties and Economic Models of Real Estate Markets. PhD dissertation, University of Berlin. 
Seyoum, M. \& Bessie, S. (2018). The Impact of National Bank of Ethiopia's 27\% Bond Purchase Directive on Credit Performance and Profitability of Private Banks. Research Journal of Finance and Accounting, 9(9), pp.41-50.

Singh, K. (2007). Quantitative Social Research Methods (1st ed.). New York: SAGE Publications Ltd.

TEGoVA. (2016). European Valuation Standards (8th ed.). Belgium.

Udoekanem, N.B. (2017). Valuation of Urban Commercial Properties in Nigeria for Secured Lending: Issues and Developments. International Journal of Built Environment and Sustainability, 5(1), pp.68-77. DOI: 10.11113/ijbes.v5.n1.247.

Yegidis, B.L., Weinbach, R.W. \& Myers, L.L. (2011). Research Methods for Social Workers (7th ed.). Pearson.

\section{Acknowledgement}

The authors would like to thank the Government of Ethiopia and the German Academic Exchange Services (DAAD) for providing the scholarship for the doctoral programme on which this article is based. Authors also grateful to thank bank valuers for their helpful suggestions and comments. 